\title{
Use of side-scan sonar for estimations of Crassostrea brasiliana (Lamarck, 1819) stocks in subtidal banks on the south coast of Brazil
}

\author{
Gisela Geraldine Castilho Westphal ${ }^{1 *}$, Antonio Ostrensky ${ }^{l}$
}

\author{
${ }^{1}$ Universidade Federal do Paraná, Setor de Ciências Agrárias, Departamento de Zootecnia. \\ (Rua dos Funcionários, 1540, Juvevê, Curitiba-PR, CEP 80035-050) \\ *Corresponding author: xlcastilho@yahoo.com.br
}

\section{Abstract}

Uncontrolled extractivism has led to a worldwide reduction in oyster stocks. The use of new and more efficient management tools for impacted environments must increase. The application of such tools requires previous biological and environmental knowledge of the resident populations of these bivalve mollusks. Technical difficulties are usually associated with studies of submerged oyster banks, and these difficulties result in a considerable lack of biological data on the oysters that inhabit subtidal zones. This study aimed to survey Crassostrea brasiliana (also known as C. gasar) stocks in submerged banks and to evaluate a method with which to measure the extent of the banks and identify and quantify the oysters in the banks with the use of side-scan sonar. This study was conducted on 10 oysters banks located in the subtidal zone of Guaratuba Bay, on the south coast of Brazil. The prospection of all these banks was later validated by diving, and oyster samples $(n=20 /$ bank) were collected for species identification with a molecular method. Only one bank contained oysters that were generically classified as Crassostrea sp.; those in the remaining banks being identified as $C$. brasiliana. The prospected banks contained oysters of various sizes (average $1.5 \mathrm{~m}, \mathrm{n}=1,107$ ) that were heterogeneously scattered in the riverbeds. The total number of oysters in the 10 sampled banks was estimated to be $21,159.13$ oysters or 1 oyster $/ 4.5 \mathrm{~m}^{2}$, which represents a low oyster density in the study site. The results validate the use of side-scan sonar as an efficient means with which to prospect for oysters in banks located within subtidal zones.

Descriptors: Mangrove forests, Prospecting, Oyster fisheries, Oyster reefs, Shellfish, Side-scan sonar.

\section{Resumo}

O extrativismo descontrolado tem levado a uma redução mundial nos estoques de ostras. Embora o uso de novas e mais eficientes ferramentas que conduzam à redução de impactos ambientais tenham aumentado, a aplicação de tais ferramentas requer conhecimento prévio de características ambientais e biológicas das populações de moluscos bivalves residentes. Dificuldades técnicas são geralmente associadas ao estudo de bancos de ostras submersos e esta dificuldade resulta em uma considerável falta de dados biológicos de ostras que habitam zonas subtidais. Este estudo objetivou pesquisar estoques de Crassostrea brasiliana (sinonímia para C. gasar) em bancos submersos e avaliar um método com o qual as medições de extensão dos bancos, identificação e quantificação das ostras nestes bancos fosse feita usando um sonar de varredura lateral. Este estudo foi conduzido em 10 bancos de ostras localizados na zona de infralitoral da baía de Guaratuba, na costa sul do Brasil. Toda a prospecção dos bancos foi validada por mergulho e amostragens de ostras ( $n=20 /$ banco), que foram coletadas para a identificação das espécies por análise molecular. Somente um banco continha ostras que foram genericamente classificadas como Crassostrea sp., enquanto os organismos dos bancos restantes foram identificados como C. $b r a-$ siliana. A prospecção de bancos revelou a existência de conjuntos de ostras de tamanho variados (média 1,5 m, n $=1.107$ ), espalhados de forma heterogênea no leito dos rios. O número total de ostras em 10 bancos amostrados foi estimado em $21.159,13$ ostras ou 1 ostra/4,5 m², o que representou uma baixa densidade para a área de estudo. Os resultados validaram o uso do sonar de varredura lateral como um eficiente mecanismo para a prospecção de ostras localizadas em bancos submersos.

Descritores: Manguezal, Prospecção, Extração de ostras, Bancos de ostras, sonar de varredura lateral. 


\section{INTRODUCTION}

Concerns about the effects of extractivism as an economic activity on oyster populations are not recent. CADERNAS (1984) described the intense exploitation of natural oyster banks on the west coast of Mexico, and MANCERA and MENDO (1996) showed evidence of the reckless exploitation, by predatory methods, of natural oyster banks in Colombia.

Centuries of resource extraction, which has been exacerbated by coastal degradation, have led oyster banks to the verge of extinction in many countries. Globally, it is estimated that $85 \%$ of the existing oyster banks have been decimated (BECK et al., 2011).

In Brazil, commercial oyster exploitation without adequate management has contributed to declines in the natural stocks. This fact is aggravated in easily accessible regions, such as the coast of the state of Paraná in southern Brazil (CHRISTO, 2006), where the shortage of oysters of the species Crassostrea brasiliana (also known as C. gasar), which are found in commercial sizes in the natural environment, has already been noted (CHRISTO, 2006; KOLM; ABSHER, 2008).

The design of an efficient stock management plan is only made possible by the knowledge and quantification of oyster populations in the environment. However, population estimate studies have been conducted primarily in intertidal banks, likely because these are easier to access. Although detailed surveys of the intertidal zone, such as those conducted by PEREIRA et al. (2000), PEREIRA et al. (2001) and ERSE and BERNARDES (2008), exist, the quantification of animals in subtidal zones is still lacking.

New studies that seek alternative ways to study benthic organisms have been begun worldwide in the last decade. In these new studies, such as those performed by DALE et al. (2002), BREHMER et al. (2003), SMITH et al. (2003), ALLEN et al. (2005), COLLIER and HUMBER (2007), OVERMEEREN et al. (2009) and BECK et al. (2011), methods that employ acoustic prospecting of the bottoms of oceans, estuaries and bays have begun to be incorporated into studies of benthic organisms.

Among the methods available for prospecting, sidescan sonar (SSS) holds great promise for quantitative descriptions of the distribution and extent of benthic habitats (ALLEN et al., 2005). This type of sonar has already been tested in studies of oyster banks (DALE et al., 2002). The use of SSS makes the mapping of large areas in a relatively short time possible while simultaneously obtaining georeferenced coordinates for any location on the image (DALE et al., op. cit.), free of influence of water turbidity or environmental light intensities (BREHMER et al., 2006). However, according to DALE et al. (op. cit.), this equipment must be used in conjunction with other biological sampling techniques such as dredging and sampling of pre-defined areas to calibrate the method.

SSS can also be used in mapping and monitoring studies of the stocks of bivalve mollusks and benthic organisms in shallow water habitats (BREHMER et al., 2003; OVERMEEREN et al., 2009). Its use has been recommended as public policy in New Zealand, where there are plans to map the banks of Crassostrea gigas and Mytilus edulis in the environment (OVERMEEREN et al., 2009).

The objective of this project was to conduct the first study of C. brasiliana oyster stocks in submerged banks and to evaluate a method by which to measure the extent of the banks and to identify and quantify the oysters in the banks using SSS.

\section{MATERIAL AND METHODS}

\section{STUDY SITE}

The site studied was Guaratuba Bay (2552'S, $\left.48^{\circ} 39^{\prime} \mathrm{W}\right)$, located in the south region of Brazil and which covers a total area of $48.72 \mathrm{~km}^{2}$ (CHAVES; BOUCHEREAU, 1999). On the north side of the bay, there are mangroves under seasonal fluvial influence, Laguncularia racemosa being the dominant species. The depth is greater than 6 meters in some areas, the salinity ranging from 3 to $37 \mathrm{gL}^{-1}$, and the temperature from 15 to $28^{\circ} \mathrm{C}$, depending on the season (GIA, 2011).

For this study, 10 natural banks within the subtidal zones were chosen at random (Figure 1); these corresponded to $25 \%$ of the total banks identified by CASTILHO-WESTPHAL (2012) at this site.

\section{Prospecting of Natural oyster Banks}

In January 2011, a prospecting survey of natural banks was conducted with a model DE340 Sound Navigation and Ranging (SONAR) Side-Scan Sonar (SSS), manufactured by Deep Vision ${ }^{\circledR}$ (Linkoping, Sweden) and operated with a maximum resolution of $10 \mathrm{~cm}$.

The use of SSS is an indirect method of data acquisition based on sound propagation in water. SSS is an active remote sensing system that emits and records sound waves to generate images of the bottom (sonographic records). The equipment emits $2340-\mathrm{KHz}$ beams with an opening angle of $\sim 30^{\circ}$. It operates by side scanning while being towed by a vessel near the surface of the water column; the signal reaches the seabed, interacts with the sediment and returns to the sensor. 


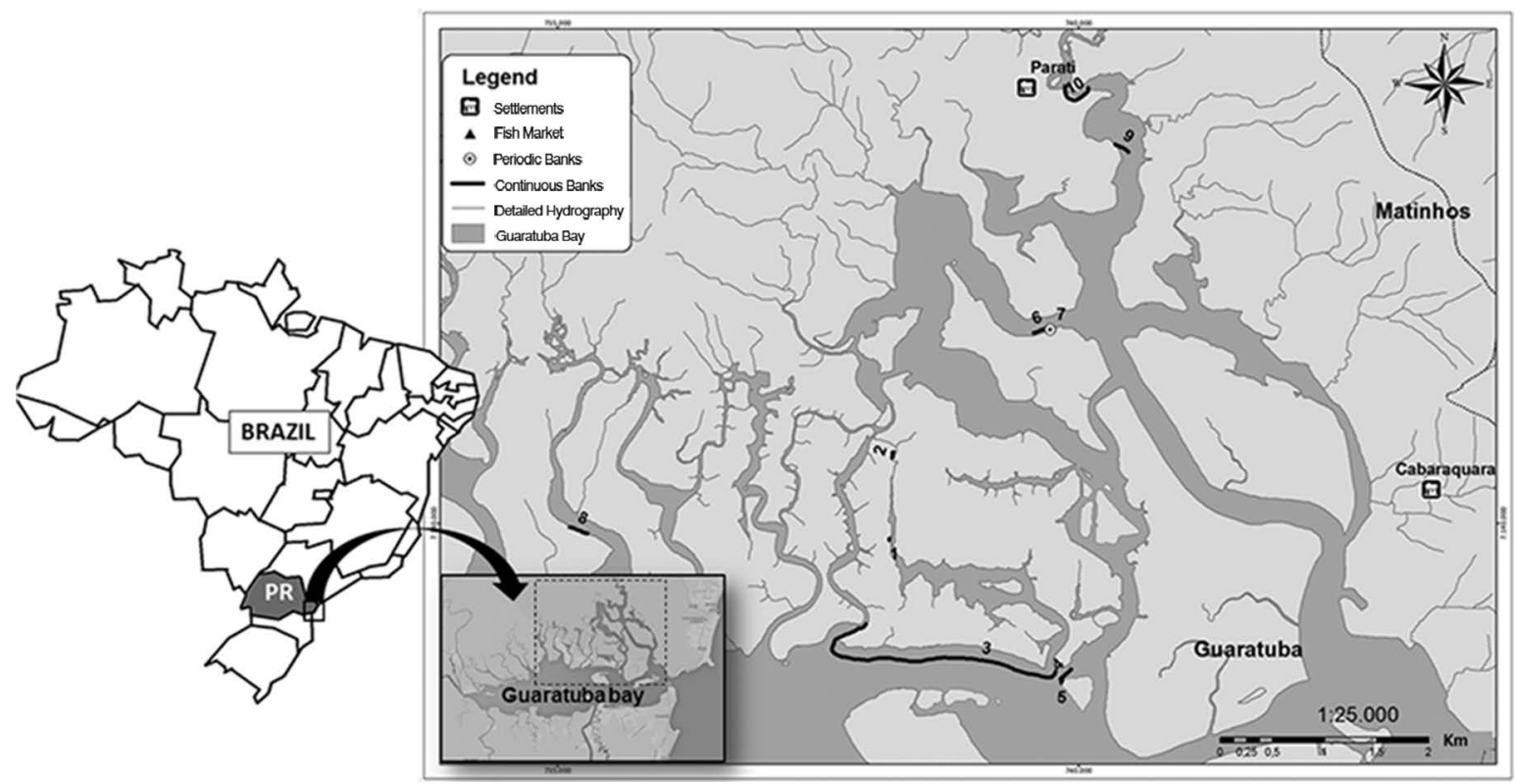

Figure 1. Subtidal natural oyster beds, Guaratuba Bay, Paraná state, Brazil. Points 1 to 10 indicate the banks prospected with SONAR. $1=$ Barigui River; 2 = Furado do Quilombo; 3 = Furado do Braço Seco; $4=$ Sambaqui do Braço Seco; 5 = Barigui; 6 = Baixio das Ostras; $7=$ Sambaqui das Cruzes; 8 = Sambaqui das Laranjeiras (Laranjeiras River); $9=$ Ariri; $10=$ Miringuava.

The sonographic records are viewed and processed with the DeepView $\mathrm{FV}^{\circledR} 3.0$ software package (2008).

The scanning lines should be uniformly arranged and can be parallel, circular radial, or zigzag (TEDESCO, 2003). In the present study, the lines followed the riverbeds and ran parallel to the margins. The selected banks were fully prospected by differentiating between the oyster sets (popularly known as "cabeças de ostras" "oyster heads") in the substrate. As a confirmatory method by which to identify the submerged banks observed by SSS, shellfish harvesters in the region conducted free dives to collect oysters from each bank.

The images generated by SSS were analyzed, and the formations observed on the beds of the prospected areas were identified and quantified and their total lengths (extent) in meters (m) were also measured with the DeepView FV ${ }^{\circledR} 3.0$ software package (2008).

\section{Oyster SAMPLING}

Each sample was composed of 20 oysters to a total of 200 live specimens, which were transported under refrigeration as recommended by the CODEX ALIMENTARIUS (1978). The total transportation time to the Laboratory of Histology and Microbiology of the Integrated Aquaculture and Environmental Studies Group [Laboratório de Histologia e Microbiologia (LHM) do Grupo Integrado de Aquicultura e Estudos Ambientais (GIA)], located in the city of Curitiba, Paraná state, was no more than 6 hours.
In the laboratory, the oysters were measured according to the model proposed by GALTSOFF (1964), rinsed and opened. Adductor muscle fragments were collected and fixed in $92^{\circ}$ ethanol for species identification according to the molecular method described by LUDWIG et al. (2011). Twenty individuals were pooled and analyzed to generate results that contained the species identified per bank.

\section{RESULTS}

\section{Prospecting of Oyster banks With SONAR}

A total area of $98,010 \mathrm{~m}^{2}$ of the riverbeds, in which oyster sets of various sizes were observed to be scattered heterogeneously, was examined by SSS (Figure 2). The average length of the oyster sets was $1.5 \mathrm{~m}(\mathrm{n}=1.107)$, with a minimum of $0.2 \mathrm{~m}$ and a maximum of $8.0 \mathrm{~m}$. The total length occupied by the banks was 1,633.5 $\mathrm{m}$ (Table 1).

From the data thus generated, the total number of oysters in the 10 sampled banks was estimated to be 21,159.13 (1,763.26 dozen) or 1 oyster/4.5 $\mathrm{m}^{2}$ (Figure. 3).

\section{SpeCIES IDENTIFICATION}

All the samples were subjected to genetic analysis for species identification. However, the genetic material of 42 individuals was inadequate for laboratory processing, and these samples were thus classified as "not analyzed" (Figure 4). 


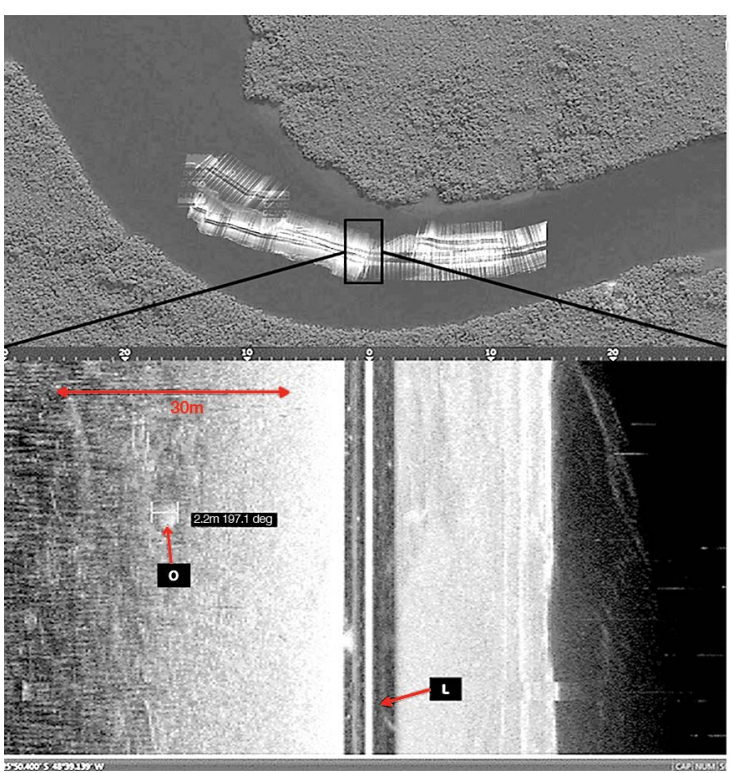

Figure 2. Image generated by SSS. Oyster set (O) in the Barigui riverbed (point 1) that measured $2.2 \mathrm{~m}$ in diameter. The vertical line in the center $(\mathrm{L})$ indicates the water column under the SSS, and the scale above indicates the values in meters $(\mathrm{m})$ with a maximum field range of $30 \mathrm{~m}$ per side.

Of the total number of oysters identified ( $\mathrm{n}=158), 96 \%$ were C. brasiliana, and 4\% were Crassostrea sp. (Figure 4).

The identification of the species captured in the subtidal banks suggested both the absence of $C$. rhizophorae and the predominance of $C$. brasiliana in this habitat. The presence of Crassostrea sp. in the subtidal banks stood out because this species had previously only been observed in Guaratuba Bay on plankton and among seeds attached to settlement plates (CASTILHO-WESTPHAL, 2012).

The discovery of Crassostrea sp. specimens in the subtidal banks coincided with reports that had been obtained by means of informal conversations with boatmen and residents in the area during the field activities. Local inhabitants reported having observed oysters that were morphologically different from those that had commonly been collected from the submerged banks in recent years (between 3 and 5 years ago, approximately). Some local inhabitants said that they believed the oysters were a new species, and others called them "clams". The specimens will later be identified at the species level because this information does not affect the results of the present study.

The biometric data for the specimens collected from each of the natural banks were significantly different $(p<$ $0.05)$ with regard to but few of the parameters. The height differed between the oysters collected from sampling point 3 and those from points 5 and 7 , and the width differed

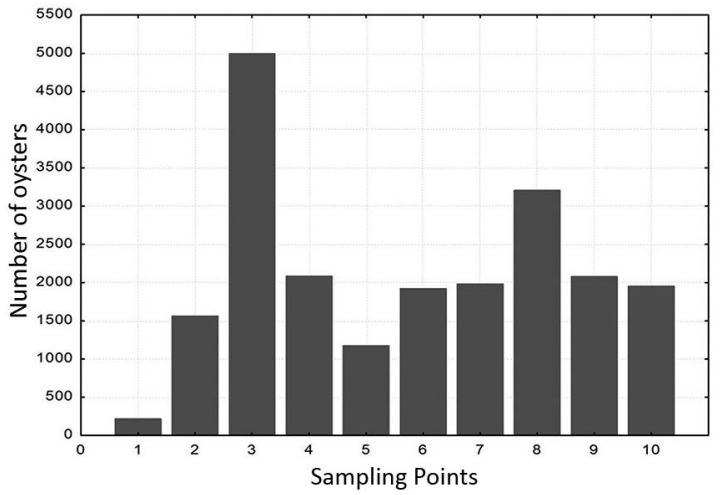

Figure 3. Total number of oysters estimated for each SSS-prospected and sampled bank in Guaratuba Bay, Paraná state. 1 = Barigui River; 2 = Furado do Quilombo; 3 = Furado do Braço Seco; 4 = Sambaqui do Braço Seco; 5 = Barigui; $6=$ Baixio das Ostras; $7=$ Sambaqui das Cruzes; $8=$ Sambaqui das Laranjeiras (Laranjeiras River); $9=$ Ariri; $10=$ Miringuava

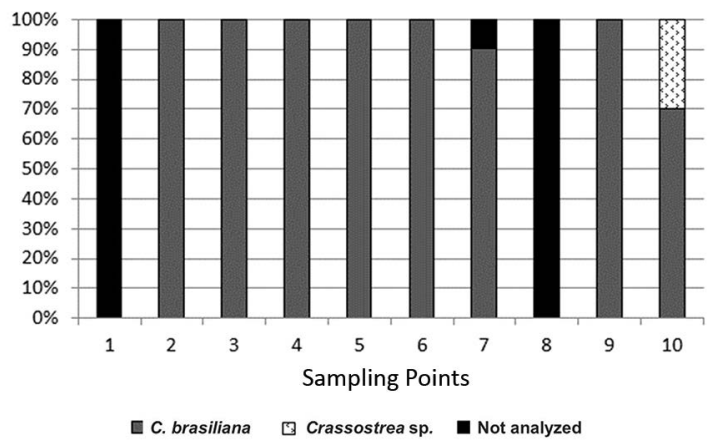

Figure 4. Percentage of Crassostrea brasiliana and Crassostrea sp. individuals in the oyster banks studied. 1 = Rio Barigui; $2=$ Furado do Quilombo; 3 = Furado do Braço Seco; 4 = Sambaqui do Braço Seco; 5 = Barigui; $6=$ Baixio das Ostras; $7=$ Sambaqui das Cruzes; $8=$ Sambaqui das Laranjeiras; $9=$ Ariri; $10=$ Miringuava. DNA samples that were unsuitable for analysis are indicated in the chart as "not analyzed".

between the animals from points 8 and 9 (Table 2). The measurements of oysters from point 9 , in which Crassostrea sp. specimens were present in the lot analyzed, were similar to those from the other points, in other words, they were similar to those of the C. brasiliana specimens.

\section{DISCUSSION}

C. gasar (DAUTZENBERG, 1891) was first reported in Brazil by LAPÉGUE et al. (2002). However, that study questioned whether $C$. gasar and C. brasiliana were the same species. Subsequently, VARELA et al. (2007) conducted studies on the molecular phylogeny of mangrove oysters from Brazil and suggested that $C$. brasiliana was a 
Table 1. Extent of the oyster banks in Guaratuba Bay as measured by SSS. Letters indicate significant differences of $p<$ 0.05 , according to the Kruskal-Wallis test. $1=$ Barigui River; 2 = Furado do Quilombo; 3 = Furado do Braço Seco; $4=$ Sambaqui do Braço Seco; 5 = Barigui; 6 = Baixio das Ostras; 7 = Sambaqui das Cruzes; $8=$ Sambaqui das Laranjeiras (Laranjeiras River); $9=$ Ariri; $10=$ Miringuava. TE = Total extent (m); IE = Individual extent (m) of the oyster of the set (median, maximum and minimum), OS = oyster set (n).

\begin{tabular}{cccccccccccc}
\hline & \multicolumn{1}{c}{ Sampling Point } & & & \\
& 1 & 2 & 3 & 4 & 5 & 6 & 7 & 8 & 9 \\
\hline TE & $14.4 \mathrm{abc}$ & $134.3 \mathrm{ac}$ & $439.2 \mathrm{ac}$ & $152.1 \mathrm{~b}$ & $84.4 \mathrm{abc}$ & $157.5 \mathrm{c}$ & $130.8 \mathrm{ab}$ & $230.8 \mathrm{ac}$ & $149.5 \mathrm{abc}$ & $140.5 \mathrm{~b}$ \\
& 1.4 & 1.6 & 1.3 & 1.0 & 1.4 & 1.8 & 1.2 & 1.4 & 1.2 & 1.0 \\
IE & $(0.8-1.6)$ & $(0.4-6.4)$ & $(0.4-6.1)$ & $(0.2-3.5)$ & $(0.6-3.1)$ & $(0.2-6.6)$ & $(0.4-3.8)$ & $(0.8-2.7)$ & $(0.4-8.0)$ & $(0.2-2.4)$ \\
& 11 & 79 & 285 & 120 & 59 & 68 & 101 & 162 & 101 & 121 \\
\hline
\end{tabular}

Table 2. Biometric data (medians, minimum and maximum values [brackets]) for the oysters collected from subtidal banks that were prospected with SSS in Guaratuba Bay (1 = Rio Barigui; 2 = Furado do Quilombo; 3 = Furado do Braço Seco; 4 $=$ Sambaqui do Braço Seco; $5=$ Barigui; $6=$ Baixio das Ostras; $7=$ Sambaqui das Cruzes; $8=$ Sambaqui das Laranjeiras; $9=$ Ariri; $10=$ Miringuava; $\mathrm{H}=$ height, $\mathrm{L}=$ length, $\mathrm{W}=$ width); $\mathrm{M}=$ measurements in centimeters, $\mathrm{H}=$ height, $\mathrm{L}=$ length, $\mathrm{W}=$ width. The letters indicate significant differences according to the Kruskal-Wallis test $(p<0.05)$.

\begin{tabular}{|c|c|c|c|c|c|c|c|c|c|c|}
\hline \multirow[b]{2}{*}{ M } & \multicolumn{10}{|c|}{ Sampling Point } \\
\hline & 1 & 2 & 3 & 4 & 5 & 6 & 7 & 8 & 9 & 10 \\
\hline $\mathrm{H}$ & $\begin{array}{c}6.7 \\
(4.0-23.1) \\
a b\end{array}$ & $\begin{array}{c}8.6 \\
(6.0-13.8) \\
a b\end{array}$ & $\begin{array}{c}8.8 \\
(6.2-17.4) b\end{array}$ & $\begin{array}{c}7.3 \\
(6.1-10.0) \\
a b\end{array}$ & $\begin{array}{c}7.2 \\
(4.5-17.3) a\end{array}$ & $\begin{array}{c}8.2 \\
(4.8-17.3) \\
a b\end{array}$ & $\begin{array}{c}6.6 \\
(5.4-10.9) \mathrm{a}\end{array}$ & $\begin{array}{c}7.2 \\
(1.8-13.0) \\
a b\end{array}$ & $\begin{array}{c}7.2 \\
(4.5-10.1) \\
a b\end{array}$ & $\begin{array}{c}7.2 \\
(4.3-10.2) \\
\mathrm{ab}\end{array}$ \\
\hline $\mathrm{L}$ & $\begin{array}{c}5.4 \\
(3.1-10.9)\end{array}$ & $\begin{array}{c}6.6 \\
(4.2-9.2)\end{array}$ & $\begin{array}{c}7.0 \\
(4.5-9.6)\end{array}$ & $\begin{array}{c}6.5 \\
(2.9-8.3)\end{array}$ & $\begin{array}{c}5.4 \\
(3.2-10.5)\end{array}$ & $\begin{array}{c}6.5 \\
(4.2-10.5)\end{array}$ & $\begin{array}{c}5.6 \\
(4.0-8.5)\end{array}$ & $\begin{array}{c}6.2 \\
(4.4-9.9)\end{array}$ & $\begin{array}{c}5.4 \\
(3.2-7.4)\end{array}$ & $\begin{array}{c}5.4 \\
(4.0-7.3)\end{array}$ \\
\hline W & $\begin{array}{c}2.3 \\
(1.5-5.9) \\
a b\end{array}$ & $\begin{array}{c}2.9 \\
(2.0-4.5) \\
\mathrm{ab}\end{array}$ & $\begin{array}{c}3.2 \\
(1.8-5.5) \\
a b\end{array}$ & $\begin{array}{c}2.8 \\
(1.9-4.0) \\
a b\end{array}$ & $\begin{array}{c}3.1 \\
(1.5-5.3) \\
a b\end{array}$ & $\begin{array}{c}3.1 \\
(1.5-5.3) \\
a b\end{array}$ & $\begin{array}{c}3.0 \\
(1.8-4.6) \\
\mathrm{ab}\end{array}$ & $\begin{array}{c}3.3 \\
(1.2-5.0) \mathrm{b}\end{array}$ & $\begin{array}{c}3.2 \\
(1.5-5.1) \\
a b\end{array}$ & $\begin{array}{c}2.3 \\
(1.6-3.5) a\end{array}$ \\
\hline
\end{tabular}

synonym for $C$. gasar, which had hitherto been considered a species endemic to the African continent.

Although the main factors that influence the distribution of species that live within the intertidal zone of an estuary are salinity and substrate (SONIAT; BRODY, 1988; TWICHELL et al., 2010), the time during which the animal is exposed to the air is also an important factor (PEREIRA et al. 2000). C. brasiliana colonization in the intertidal (CASTILHO-WESTPHAL, 2012; CASTILHOWESTPHAL et al., 2014) and subtidal zones, which has been observed in this article as also by GALVÃO et al. (2012), suggests that exposure to air (during low tide) is not a limiting factor for the occupation and survival of the species.

Affinity with the subtidal environment does not apply to $C$. rhizophorae, which is better suited to the intertidal zone and thus was not observed in the submerged banks in this study; as was also commented by GALVÃO et al. (2012). The same cannot be said of Crassostrea sp., whose specimens were collected from both the subtidal (point 10) and intertidal zones (CASTILHO-WESTPHAL, 2012). This species is still poorly known, and MELO et al. (2010) reported organisms that most likely belonged to this species, which were found among seeds that had been attached to artificial collectors placed in mangrove forests in the municipality of Bragança, Pará state, northern Brazil. In the following year, LUDWIG et al. (2011) likely observed the same animal in artificial collectors and among larvae present in the plankton in Guaratuba Bay (CASTILHO-WESTPHAL, 2012). According to MELO et al. (op. cit.), these oysters, whose species has not yet been defined, are genetically similar to Indo-Pacific oysters and might have reached the Atlantic Ocean before the closure of the Isthmus of Panama or, more recently and accidentally, might have been brought to Brazil on/ by ships. Similar to $C$. gigas oysters, which can attach themselves to muddy and/or sandy bottoms (FAO, 2012), Crassostrea sp. specimens were found in submerged banks.

With respect to the biometrics of the animals sampled, although CHRISTO (2006) describes C. brasiliana as a large species that can grow to more than $20 \mathrm{~cm}$ in height, only point 1 displayed an animal larger than this threshold $(23.1 \mathrm{~cm})$. At the other points, all of the animals 
were smaller than $20 \mathrm{~cm}$. This finding could indicate a decrease in the heights of the population present within the subtidal zone of Guaratuba Bay. Possibly, this result is a reflection of the high degree of stock exploitation, which may have reached or be reaching the point at which natural recovery is hindered. The fact that $C$. brasiliana populations from natural banks display a slow growth rate (PEREIRA et al., 2003) is also of interest. According to the authors, $72 \%$ of the intertidal populations that they assessed reached the minimum commercial size $(50 \mathrm{~mm})$ only after 28 months.

The use of SSS equipment, as described by OVERMEEREN et al. (2009), proved to be a suitable method with which to monitor the oyster habitats quantitatively. In turn, the collections from and visual observations of banks provided irrefutable evidence of the presence of these species and also served as a means for the calibration and validation of the method, as suggested by GRIZZLE et al. (2008), OVERMEEREN et al. (op. cit.) and BROWN et al. (2011). Aside from bottom sampling, other methods complementary to SSS could be used for calibration and to promote more accurate results, such as sampling the shells of dead animals (SAURIAU et al., 1997) and the joint use of the air-gun and bathymetric methods (TWICHELL et al., 2010).

On the one hand, the analysis was a methodological success, on the other, the data generated by SSS and biometric analyses and the values of the catch per unit effort (CPUE), described by CASTILHO-WESTPHAL (2012), for the site reveal a worrying aspect of the conservation of this natural resource. This is because, with a CPUE that ranged from 22.5 to 5,400 dozen/year/extractor and an estimated total of only 1,763.3 dozen oysters in the 10 banks sampled, which account for $32 \%$ of the subtidal banks described by CASTILHO-WESTPHAL (2012) and Castilho-Westphal et al. (in press), it appears that the 3 or 4 shellfish harvesters who knew the locations of the sampled banks could alone decimate them. Furthermore, the number of oysters per unit area sampled in Guaratuba Bay is close to the lowest values that have been recorded for the species in intertidal banks (PEREIRA et al., 2000). The situation has most likely not yet reached a point of no return only because the harvesters of shellfish have not limited their activity to the subtidal banks but have also exploited the intertidal banks that are dominated by $C$. rhizophorae, thus diminishing the pressure on the $C$. brasiliana banks. However, this will slow but not prevent the irreversible impact of the uncontrolled exploitation of those banks.
Thus, this study has confirmed the efficiency of SSS equipment for the prospecting of $C$. brasiliana in subtidal banks, the low prevalence of this mollusk in the banks of Guaratuba Bay and the clear signs of overexploitation and risks of irreversible impacts to the local populations of this species.

\section{ACKNOWLEDGEMENTS}

The authors wish to thank Prof. Dr. Alvin Fernando Veiga, Geology Department, Federal University of Paraná (Universidade Federal do Paraná - UFPR) for his valuable suggestions as to the use of the SSS equipment, and Bruno and Luiz of the same department for their assistance with field work and data analysis. Our thanks are also due to: Adriano Hauer for supporting the field activities, and the boatmen and divers Adriano, Luis and Silvio; Alexandre Guilherme Beker, M.S. for creating the map, and Leandro A. Pereira for suggestions on the conduct of this research; Professor Walter Boeger, Sandra Ludwig, Raquel Patella, Luciana Patella and Raphael Orelis for their great help in performing the molecular analysis. We are also indebted to Petrobras's (Petróleo Brasileiro $\mathrm{S} / \mathrm{A}$ ) Development and Citizenship program (Petrobras programa Desenvolvimento e Cidadania), the Boticário Group Nature Protection Foundation (Fundação Grupo Boticário de Proteção à Natureza), HSBC Solidarity Institute (Instituto HSBC Solidariedade) and the Ministry of Fisheries and Aquaculture (Ministério da Pesca e Aquicultura) for funding this research, as well as to the National Council for Scientific and Technological Development (Conselho Nacional de Desenvolvimento Científico e Tecnológico - CNPq), without which this research would not have been possible.

\section{REFERENCES}

ALLEN, Y. C.; WILSON, C. A.; ROBERTS, H. F.; SUPAN, J. High resolution mapping and classification of oyster habitats in nearshore Louisiana using sidescan sonar. Estuaries, v. 28, n. 3, p. 435-446, 2005.

BECK, M. W.; BRUMBAUGH, R. D.; AIROLD, L.; CARRANZA, A.; COEN, L. D.; CRAWFORD, C.; DEEFO, O.; EDGAR, G. J.; HANCOCK, B.; KAY, M. C.; LENIHAN, H. S.; LUCKENBACH, M. W.; TOROPOVA, C. L.; ZHANG, G.; GUO, X. Oyster Reefs at Risk and Recommendations for Conservation, Restoration, and Management. BioScience, v. 61, n. 2, p. 107-116, 2011.

BREHMER, P.; GERLOTTO, F.; GUILLARD, J.; SANGUINÈDE, F.; GUÉNNEGAN, Y.; BUESTEL, D. New applications of hydroacoustic methods for monitoring shallow water aquatic ecosystems: the case of mussel culture grounds. Aquat. Living Resour., v. 16, p. 333-338, 2003. 
BREHMER, P.; VERCELLI, C.; GERLOTTO, F.; SANGUINÈDE, F.; PICHOT, Y.; GUENNÉGAN, Y.; BUESTEL, D. Multibeam sonar detection of suspended mussel culture grounds in the open sea: Direct observation methods for management purposes. Aquaculture, v. 252, n. 2/4, p. 234-241, 2006.

BROWN, C. J.; SMITH S. J.; LAWTON, P.; ANDERSON, J. T. Benthic habitat mapping: a review of progress towards improved understanding of the spatial ecology of the seafloor using acoustic techniques. Estuar. Coast. Shelf Sci., v. 92, n. 3, p. 502-520, 2011

CADERNAS, E. B. Status of molluscan aquaculture on the Pacific coast of Mexico. Aquaculture, v. 39, n. 1/4, p. 83-93, 1984.

CASTILHO-WESTPHAL， G. G. Ecologia da ostra do mangue Crassostrea brasiliana (Lamarck, 1819) em manguezais da Baía de Guaratuba-PR. 2012. 118 f. Tese (Doutorado) - Universidade Federal do Paraná, Brasil, 2012. Available from: <http://dspace.c3sl.ufpr.br/dspace/ bitstream/handle/1884/28121/R\%20-\%20T\%20-\%20 GISELA\%20GERALDINE\%20CASTILHO-WESTPHAL. pdf?sequence=1>. Accessed: 20 Sep. 2014.

CASTILHO-WESTPHAL， G. G.; DAL PONT, G.; HORODESKY, A.; OSTRENSKY, A. Riverine gatherers communities and the exploitation of the mangrove oysters beds Crassostrea sp., in Guaratuba bay - Paraná, southern Brazil. Biosci. J., v. 30, n. 2, p. 912-923, 2014.

CHAVES, P. T. C.; BOUCHEREAU, J. L. Biodiversité et dynamique des peuplements ichtyiques de la mangrove de Guaratuba, Brésil. Oceanol. Acta, v. 22, n. 3, p. 353-364, 1999.

CHRISTO, S. W. Biologia reprodutiva e ecologia de ostras do gênero Crassostrea Sacco, 1897 na baía de Guaratuba (Paraná - Brasil): um subsídio ao cultivo. Tese (Doutorado) - Universidade Federal do Paraná, Curitiba. Brasil, 2006. Available from: < http:// dspace.c3sl.ufpr.br/dspace/bitstream/handle/1884/5198/Tese. pdf?sequence=1>. Accessed: 20 Sep. 2014.

Código Internacional Recomendado de Prácticas de Higiene para Mariscos Moluscoides, CAC/RCP. Codex Alimetarius, v. 18, n. 9, p. 1-29, 1978.

COLLIER, J. S.; HUMBER, S. R. Time-lapse side-scan sonar imaging of bleached coral reefs: a case study from the Seychelles. Remote Sens. Environ., v. 108, n. 4, p. 339-356, 2007.

DALE, D.; CUEVAS, K.; BUCHANAN, M.; GORDON, S.; PERET, W. S. Side scan sonar in oyster management. Oceans '02 MTS/IEEE, v. 1, p.141-145, 2002.

ERSE, E. B.; BERNARDES, M. A. Levantamento de estoques da ostra Crassostrea sp. em bancos naturais no litoral paranaense. Biotemas, v. 21, n. 2, p. 57-63, 2008.

FAO - Food and Agriculture Organization of the United Nations. 2012. Species Fact Sheets Crassostrea gigas (Thunberg, 1793). Available from: <http://www.fao.org/fishery/ species/3514/en>. Accessed: 14 Sept. 2014.

GALTSOFF, P. S. The american oyster Crassostrea virginica. Fish. Bull., v. 64, p. 1-480, 1964.

GALVÃO, M. S. N.; Pereira, O. M.; Hilsdorf, A. W. S. 2012. Molecular identification and distribution of mangrove oysters (Crassostrea) in an estuarine ecosystem in Southeast Brazil: implications for aquaculture and fisheries management. Aquac. Res., pp.1-13.
GIA - Grupo Integrado de Aquicultura e Estudos Ambientais. 2011. Planos Locais de Desenvolvimento da Maricultura (PLDM's). Brasília: Ministério da Pesca e Aquicultura, 2011. $575 \mathrm{p}$.

GRIZZLE, R. E.; BRODEUR, M. A.; ABEELA, H. A.; GREENE, J. K. Bottom habitat maping using towed underwater videography: subtidal oyster reefs as an example application. J. Coast. Res., v. 24, n. 1, p. 103-109, 2008.

KOLM, H. E.; ABSHER, T. M. Bacterial density and coliform organisms in waters and oysters of Paranaguá Estuarine Complex, Paraná, Brazil. Bol. Inst. Pesca, v. 34, n. 1, p. 4959, 2008

LAPÉGUE S., Boutet I., Leitão A., Heurtebise S., Garcia P., Thiriotuiévreux C., Boudry P. 2002. Trans-Atlantic distribution of a mangrove oyster species revealed by $16 \mathrm{~S}$ mtDNA and karyological analyses. Biol. Bull. 202, 232-242.

LUDWIG, S.; PATELLA, R.; STOIEV, S.; CASTILHOWESTPHAL, G. G.; GIROTTO, M. V. F.; OSTRENSKY, A. A molecular method to detect and identify the native species of southwestern Atlantic Crassotrea (Mollusca: Ostreidae). Zoologia, v. 28, n. 4, p. 420-426, 2011.

MANCERA, J.; MENDO, J. Population dynamics of the oyster Crassostrea rhizophorae from the Cienaga Grande de Santa Marta, Colombia. Fish. Res., v. 26, p. 139-148, 1996.

MELO, A. G. C.; VARELA, E. S.; BEASLEY, C. R.; SCHNEIDER, H.; SAMPAIO, I.; GAFFNEY, P. M.; REECE, K. S.; TAGLIARO, C. H. Molecular identification, phylogeny and geographic distribution of Brazilian mangrove oysters (Crassostrea). Genet. Mol. Biol., v. 33, n. 3, p. 564-572, 2010.

OVERMEEREN, R. V.; CRAEYMEERSCH, J.; DALFSEN, J. V.; FEY, F.; HETEREN, S. V.; MEESTERS, E. Acoustic habitat and shellfish mapping and monitoring in shallow coastal water - sidescan sonar experiences in the Netherlands. Estuar. Coast. Shelf Sci., v. 85, n. 3, p. 437448, 2009.

PEREIRA, O. M.; MACHADO, I. C.; HENRIQUES, M. B.; GALVÃO, M. S. N.; BASTOS, A. A. Avaliação do estoque da ostra Crassostrea brasiliana (Lamarck, 1819) no manguezal da região estuarino-lagunar de Cananéia $\left(25^{\circ} \mathrm{S} ; 48^{\circ} \mathrm{W}\right)$. Bol. Inst. Pesca, v. 26, n. 1, p. 49-62, 2000.

PEREIRA, O. M.; MACHADO, I. C.; HENRIQUES, M. B.; YAMANAKA, N. Avaliação do estoque da ostra Crassostrea brasiliana em rios e gamboas da região estuarino-lagunar de Cananéia (São Paulo, Brasil). Bol. Inst. Pesca, v. 27, n. 1, p. 85-95, 2001a.

PEREIRA, O. M.; HENRIQUES, M. B.; MACHADO, I. C. Estimativa da curva de crescimento da ostra Crassostrea brasiliana em bosques de mangue e proposta para sua extração ordenada no estuário de Cananéia, SP, Brasil. Bol. Inst. Pesca, v. 29, n. 1, p. 19-28, 2003.

SAURIAU, P. G.; PICHOCKI-SEYFRIED, C.; WALKER, P.; MONTAUDOUIN, X.; PALUD, C.; HÉRAL, M. Crepidula fornicata L. (mollusque, gastéropode) en baie de MarennesOléron: cartographie des fonds par sonar à balayage latéral et estimation du stock. Oceanol. Acta, v. 21, n. 2, p. 353-362, 1997.

SMITH, G. F.; ROACH, E. B.; BRUCE, D. G. The location, composition, and origin of oyster bars in mesohaline Chesapeake Bay. Estuar. Coast. Shelf Sci., v. 56, n. 2, p. 391409, 2003. 
SONIAT, T. M.; BRODY, M. S. Field validation of a habitat suitability index model for the American oyster. Estuaries, v. 11, n. 2, p. 87-95, 1988.

TEDESCO, A. Estimativa de profundidades utilizando imagens de alta resolução apoiadas por dados de levantamento batimétrico. 2003. Dissertação (Mestrado) - Universidade Federal do Paraná, Curitiba. Brasil, 2003. Available from: $<$ http://dspace.c3sl.ufpr.br/dspace/handle/1884/6781>. Accessed: 14 Sep. 2014.
TWICHELL, D.; EDMISTON, L.; ANDREWS, B.; STEVENSON, W.; DONOGHUE, J.; POORE, R.; OSTERMAN, L. Geologic controls on the recent evolution of oyster reefs in Apalachicola Bay and St. George Sound, Florida. Estuar. Coast. Shelf Sci., v. 88, n. 3, p. 385-394, 2010.

VARELA, E. S.; Beasley, C. R.; Schneider, H.; Sampaio, I.; Marques-Silva, N. S.; Tagliaro, C. H. 2007. Molecular phylogeny of mangrove oysters (Crassostrea) from Brazil. J. Mollus. Stud. 73(3), 229-234. 